\title{
Disbelief in Othello
}

BALZ ENGLER

Abstract: Belief and disbelief play an important role in Othello: between the figures and between the action and the audience. The focus here is on audience reactions. They are notoriously difficult to determine as they are poorly documented. Two general factors apart from historical evidence are used here to sketch them: the difference between reading and attending a performance, and the generic frames suggested by the play: comedy, tragedy and, in Shakespeare's own time, the morality play. Audiences would easily get confused. It may be surprising, then, that Othello is the Shakespeare play where the most violent audience reactions are documented. It may be the very confusion produced by it that is responsible for them.

Coleridge has proved to be a master of coining memorable phrases that summarise concepts, phrases that have gratefully been taken up by critics after him. One of these is certainly "the willing suspension of disbelief," another is Iago's "motivehunting of motiveless malignity." The two occur in entirely different contexts but we may still ask ourselves whether there is a link between them.

In the following paper, different examples of disbelief in Othello will be discussed, with the aim of showing how they affect the audience. The play is full of these: what seems to be black turns out to be white, white black, what seem to be banal objects turn out to be world-shattering, and what seems to be the self-control of the hero turns into wild rage, etc.

The play has been characterised as being about narratives — Othello's narratives that gained Desdemona's love, Iago's diverse narratives about Othello, Desdemona, and Cassio (Hankey 7-9), narratives to be trusted or disbelieved. They work on two levels: as addressed to other figures in the play and as addressed to the audience. Examples of disbelief within the play will be touched on, but the focus will be on the relationship between the play and its audience, where two moments play a particular role, Iago's soliloquy at the end of the first act and the killing 


\section{BALZ ENGLER}

of Desdemona in the fifth. This will also mean a return to Coleridge's notion of the "willing suspension of disbelief," which, it should be noted, was not articulated with respect to the theatre but to the relationship between readers and texts in poetry.

At the centre of the play there is the brilliant scene, 3.3, which cannot be discussed in detail here, in which Iago successfully manages to destroy Othello's love for Desdemona, by innuendo mainly in the form of seemingly innocent questions. Othello has accepted what Iago, "this fellow . . of exceeding honesty" (3.3.262) has told him, when Desdemona enters, and he exclaims:

\footnotetext{
Look where she comes:

If she be false, $\mathrm{O}$ then heaven mocks itself,

I'll not believe't. (3.3.281-283)
}

He is obviously referring to his belief that outward beauty and perfection of character correspond to each other. Desdemona, on the other hand, does not believe in such a correspondence as she "saw Othello's visage in his mind" (1.3.253) and continues to believe in this perception, in spite of what she has to go through in the play. Iago's disbelief, of which he informs us in his soliloquy at the end of the first act (1.3.382-403), is of quite a different kind. I shall come back to him later on.

But let us turn to disbelief and the audience. Audience response is notorious for being poorly documented, and where it is documented in reports and criticism, it shows that it may change in the course of history. As students of literature, we therefore tend to focus on moments when the text seems to determine the expected response, or we may even take it for granted that this is the case throughout. This is so even when we are aware of the historicity of the text.

This makes our lives easier, but it is questionable for at least two reasons: it matters in what medium we encounter the text, on the page or on the stage, and it matters how our expectations shape our understanding of the text, both by what we bring to it and by the frame of encyclopaedic knowledge the text calls up with us. Spectators reared on two-and-a-half centuries of Shakespeare worship will react differently from those in 1604 when Othello was first performed. Their reaction will be shaped, for example, by the critical notion promoted by Bradley in his Shakespearean Tragedy (1904) that Shakespeare's tragedies all follow a similar pattern.

Coleridge introduced the formula of the "willing suspension of disbelief" in a very specific context, writing about the way he and Wordsworth defined their roles in the project of Lyrical Ballads: 
it was agreed, that my endeavours should be directed to persons and characters supernatural, or at least romantic, yet so as to transfer from our inward nature a human interest and a semblance of truth sufficient to procure for these shadows of imagination that willing suspension of disbelief for the moment, which constitutes poetic faith. (Coleridge 314)

He seems to have in mind the experience of a reader, a fully focused individual, bending over a book, in a way that William Butler Yeats memorably described as follows: "When a man takes a book into the corner he . . turns away from a friend" (Yeats 207).

The Romantic critics commenting on Shakespeare's works indeed wrote about what they had read rather than what they had seen on stage. Charles Lamb, in his essay "On the Tragedies of Shakespeare, considered with reference to their fitness for Stage Representation" (1811), goes as far as arguing that "the plays of Shakespeare are less calculated for performance on a stage, than those of almost any other dramatist whatever."

\footnotetext{
What we see upon a stage is body and bodily action; what we are conscious of in reading is almost exclusively the mind, and its movements: and this, I think, may sufficiently account for the very different sort of delight with which the same play so often affects us in the reading and the seeing. (Lamb 207)
}

Hence the interest in the psychology of the protagonists, characteristic of critics in the Romantic tradition. Hence also the soliloquizing of the protagonists understood as pure expression, giving us access to a figure's mind.

In the theatre, it is more difficult to create the conditions for a "willing suspension of disbelief" of the kind to which Coleridge refers, for a number of reasons: in addition to the inadequacy of stage-representation criticised by Lamb, there are other factors that make the reactions of spectators different from those of readers. The familiar faces of actors and actresses will challenge the suspension of disbelief. But first of all, spectators' reactions are social rather than individual; they react both to their fellow spectators and to what is presented to them on stage. Unlike readers, who can ponder a passage, spectators are forcefully pulled along. Moreover, in a daylight performance, like at Shakespeare's Globe (both Elizabethan and modern), the visual focus on individual figures does not exist. We should note that the auditoria only began to be darkened in the second half of the nineteenth century, 


\section{BALZ ENGLER}

in a move that may be understood as an attempt to make the spectators' experience more like that of readers.

Apart from these general theatrical conditions, there are dramaturgical features of Othello that affect belief and disbelief, and specifically, the mixture of genres: tragedy, comedy, morality. The title of the play suggests one generic frame. All the early texts call it a tragedy in their titles. But does it show a tragic hero? Black Othello as a tragic hero has remained a controversial figure - certainly also due to the racism that has been so common in the Western tradition. In early modern drama, black figures are associated with lewdness and cruelty, like Aaron in Shakespeare's Titus Andronicus. Allegorically, their blackness would connect them with evil, with the devil. Othello is the only black hero in Elizabethan drama - Shakespeare was following his source in Cinthio and made full use of the opportunities it offered. It is not surprising, under these circumstances, that the contrast between Othello's skin colour and the nobility of his mind is thematised again and again in the play. Early on, the Duke reminds Brabantio (and implicitly the audience): "If virtue no delighted beauty lack, / Your son-in-law is far more fair than black" (1.3.290-291). Even Iago acknowledges that Othello is "of constant, loving, noble nature" (2.1.272).

In 1693, Thomas Rymer, admittedly guided by neoclassical principles, put it most brutally: "With us a Blackamoor might rise to be a Trumpeter" (Rymer 134), but certainly not a general. In the nineteenth century, in the so-called bronze age of Othello production, Othello was given lighter skin (Thompson 31), turning him into a quasiwhite person, to make the story of a tragic hero more believable.

But it is not only racist prejudice that questions the credibility of Othello as a familiar type of tragic hero. The ending of the play, for example, is unusual in that the hero's qualities are not celebrated, except in a subordinate clause, "for he was great of heart" (5.2.359), a phrase that might mean "upset" anyway, by a minor figure, Cassio, and the Venetians immediately turn to distributing his possessions (Engler). In other words, for the audience, framing the play as a tragedy has been fraught with problems, not only because of the nature of its hero.

Moreover, the play begins like a comedy, in the tradition of the commedia dell'arte: there is a Venetian street scene; there is the figure of the jealous old father (Brabantio, based on Pantalone), there is the mature man marrying a young woman, there is foolish Roderigo, and there is, of course, the clever servant who deceives his master and informs the audience about his plans. But comic elements also appear later in the play. 
There is Desdemona's lost handkerchief, which, among other things, led Thomas Rymer to reject the play as a tragedy:

There is in this Play, some burlesk, some humour, and ramble of Comical Wit, some shew, and some Mimickry to divert the spectators: but the tragical part is, plainly none other, than a Bloody Farce, without salt or savour. (Rymer 164)

There is a third generic element beside tragedy and comedy to complicate framing for the audience: the morality play, a form of medieval and Tudor entertainment that pitched allegorical figures such as Vice, Good Deeds, or Death against each other, fighting for the soul of a human being. The Vice figure continued to be popular well into the Shakespearean period. In Shakespeare, figures that still offer elements of the moralities include Aaron in Titus Andronicus (a Moor!), Falstaff, Richard III, Edmund in King Lear, and Don John in Much Ado About Nothing. These figures delight in mischief for its own sake; they tend to be masters of verbal wit and like to offer didactic comment on the action, addressing the audience directly. And they do not really need psychological motivation. The most impressive exemplar is certainly Iago.

Iago's first soliloquy at the end of the first act (1.3.382-403) marks a crucial moment. Iago, so far a comical figure, switching from prose to verse, tells the audience about his motives and his plans. It is in a note on this soliloquy that Coleridge coined the phrase "the motive-hunting of motiveless Malignity" (Shakespearean Criticism 1:44). In this speech alone, Iago offers three different motives (he will indicate more later on): he wants Cassio's position, or at least take revenge for not having been promoted himself; he suspects Othello to have slept with his wife, Emilia; and he wants to satisfy his sense of power ("to plume up my will"). He then goes on to explain his plans:

let's see:

After some time to abuse Othello's ear

That [Cassio] is too familiar with his wife.

The Moor is of a free and open nature

That thinks men honest that but seem to be so,

And will as tenderly be led by th' nose

As asses are.

I have't, it is engendered! Hell and night

Must bring this monstrous birth to the world's light. (1.3.392-394, 398-403) 


\section{BALZ ENGLER}

In his soliloquy, Iago suddenly addresses the audience directly, for the first time in the play. He does so in the tradition of the Vice. He invades our space. He claims our confidence, and makes us, willingly or unwillingly, accessories to the crimes he is planning. Our reaction is bound to be both fascination and horror, because of what he has to tell and how he involves us in the action, but also because he crosses the magical line that in the theatre divides the worlds of the audience from that of the stage.

All these elements, the distance inherent in the conditions of theatrical performance (unlike in reading), the unusual protagonist, the changing frames offered to the audience, and the role of Iago as both an agent of the action and a guide of the audience, suggest a self-conscious response by the audience, which continually has to redefine its role. As Ayanna Thompson has argued, the perfect audience of Othello should be "not only engaged and thoughtful, but also sceptical and wary" (Thompson 115). ${ }^{1}$

Under these circumstances, it may come as a surprise to learn that Othello seems to be the Shakespeare play that has produced the strongest audience reactions, ${ }^{2}$ reactions based on members of the audience giving up disbelief. Among the reactions reported there are swoonings, miscarriages, threats and attempted murder. At an 1825 performance of the play, an audience member is reported to have shouted at Edwin Forrest's Iago: "You damn'd lying scoundrel, I would like to get hold of you after the show is over and wring your infernal neck" (qtd. in Hankey 1), accepting and confusing stage and audience realities in an interesting fashion.

But the strongest reactions have been documented for the scene where Othello murders Desdemona (5.2) on the open stage, by smothering her on their marriage bed. The first example comes from 1610:

\footnotetext{
But truly the celebrated Desdemona, slain in our presence by her husband, although she pleaded her case very effectively throughout, yet moved [us] more after she was dead, when lying on her bed, entreated the pity of the spectators by her very countenance. (Thompson 41)
}

1 "While Othello continues to inspire artists, audience members and scholars to re-tell the story as a way to control the play's stories, frames and contexts, it really should inspire a new breed of listener, one who can discern the significance and validity of those stories, frames and contexts" (Thompson 116).

2 "the most conspicuous feature of the play's theatrical life has been [its] extraordinary capacity to swamp aesthetic detachment" (Shakespeare, ed. Neill 8). 
Interestingly, Ayanna Thompson alludes to Coleridge when commenting on the passage: "The audience at the Oxford performance willingly suspend their disbelief . .." (Thompson 41). After all, it was a boy actor who played Desdemona.

The most violent reaction is reported in an article by Stendhal:

\begin{abstract}
Last year (August 1822) a soldier who was standing guard in the theatre in Baltimore, upon seeing Othello, in the fifth act of the tragedy of that name, about to kill Desdemona, cried out: "It will never be said that in my presence a damned nigger killed a white woman." At the same moment the soldier shot at the actor who was playing Othello and broke his arm. $(22)^{3}$
\end{abstract}

In both cases from the early nineteenth century, the line between the world of the stage and that of the audience was transgressed, albeit in the opposite direction from Iago's soliloquy at the end of the first act.

How do these reactions go together with what has been said about an ideally sceptical audience? Obviously, the audience member shouting at Iago and the soldier shooting at Othello were confused by conflicting expectations. ${ }^{4}$ In their case, the suspension of disbelief was not willing and did not give access to poetic truth, but it was overpowering and the reaction was one of falling back onto one's most primitive attitude.

These are extreme cases. I myself have never felt tempted (or forced) to react like this to Othello (in other cases, yes). But I remember a production of the play directed by the German/English director Peter Zadek in 1976, in which Othello was presented like a golliwog, and the first scenes were played as a farce. After an initial revulsion against such a treatment of Shakespeare's tragedy, my defences were broken down, and I could no longer resist laughing heartily, and then, when the mood changed, I noticed how the confusion I had gone through made the experience almost unbearably intense. ${ }^{5}$

Disbelief: the play is full of stories that are difficult to believe, where figures, especially males, are successfully challenged to overcome their disbelief, and where we, as an audience, are tempted to do the same. We are buffeted between different

3 Michael Bristol (157) has not been able to verify the correctness of this report from other sources.

4 Laurie Maguire, in an excellent essay that only came to my attention after completing this essay comes to similar conclusions: “Audience members, I suggest, are responding to the play's own confusion of boundaries" (27).

5 In the course of the performance the black colour on Othello's skin came off. 


\section{BALZ ENGLER}

possibilities. We have to move between different generic expectations, and between the worlds of the stage and the audience. As I have mentioned, Ayanna Thompson has suggested the perfect audience should be "not only engaged and thoughtful, but also sceptical and wary" (Thompson 115). I am not so sure.

\section{Works Cited}

Bristol, Michael D. Big-time Shakespeare. New York and London: Routledge, 1996. Coleridge, Samuel Taylor. Samuel Taylor Coleridge. Ed. H.J.Jackson. Oxford: Oxford University Press, 1985.

-. Shakespearean Criticism. Ed. Raysor, Thomas Middleton. 2 vols. London: J. M. Dent \& Sons, 1960.

Engler, Balz. “Othello's Great Heart.” English Studies 68.2 (1987): 129-136.

Hankey, Julie. Introduction. Othello. By William Shakespeare. Bristol: Bristol Classical Press, 1987. 1-134.

Lamb, Charles. "On the Tragedies of Shakespeare, considered with reference to their fitness for Stage Representation." In Shakespeare Criticism, 1623-1840. Ed. Smith, D. N. Oxford: Oxford University Press, 1963. 190-212.

Maguire, Laurie. "Othello, Theatre Boundaries, and Audience Cognition." In Othello: The State of Play. Ed. Orlin, Lena Cowen. London: Bloomsbury Publishing, 2014. 17-44.

Rymer, Thomas. The Critical Works. Ed. Zimansky, Curt. New Haven: Yale University Press, 1956.

Shakespeare, William. Othello. Ed. Honigmann, E. A. J., Revised edition. London and New York: Bloomsbury Arden Shakespeare, 2016.

—. Othello. Ed. Neill, Michael. Oxford: Oxford University Press, 2006.

Stendhal, Racine and Shakespeare. Trans. Guy Daniels. New York: Crowell-Collier Press, 1962.

Thompson, Ayanna. Introduction. Othello. By William Shakespeare. Ed. Honigmann, E. A. J., Revised edition. London and New York: Bloomsbury Arden Shakespeare, 2016. 1-116.

Yeats, William Butler. "Poetry and the Living Voice." Explorations. London: Macmillan, 1962. 202-221. 


\section{Contributor Details}

Balz Engler is Professor emeritus of English Literature at Basel University, Switzerland. He has published studies on the relationship between poetic texts and their modes of communicating and on literature as performance and its cultural implications. He has edited nine collections of essays, on topics like community drama, the history of English studies in Europe, and Shakespeare in European culture. His latest publication is Constructing Shakespeares: Essays on the Making of a Great Author. 